logist ; Dr. John B. Loefer, biologist and authority on micro-organisms; Robinson Brown, mechanical engineer and oil equipment expert; Dr. Judson Swearingen, chemical engineer and authority on high-pressure processing, blowers and turbines; Dr. Paul A. Keesee, veterinarian known for his work in artificial insemination; Dr. F. W. Bieberdorf, botanist and authority on plant pathology ; Mr. I. O. Gilbert, specialist in electronics and machine design.

The first laboratory of the Southwest Research Institute, functionally designed and equipped with modern instruments and machines, houses chemical and biological laboratories, engineering department, a complete machine shop with foundry, forge, tin shop, welding and heat-treating equipment, an animal room as part of the biological section, and various cold rooms, sustained humidity rooms, a self. contained power plant, distillation plant, and other scientific facilities. A separate, underground vault for storage of volatile chemicals is located near by. The Institute is the third and largest unit affiliated with the Foundation of Applied Research, an earlier organisation established by Mr. Slick and other trustees. The first unit of the Foundation is Essar Ranch, widely known for its pure-bred Hereford and Aberdeen-Angus cattle, its experimental crossbreeding of Angus and Brahman strains to produce a hardy beef cattle for tropical regions, and artificial insemination experiments. The second is the Institute of Inventive Research, which provides inventors with a complete processing service without cost.

\section{Coconut Conference}

BECAUSE of the present world shortage of vegetable oils and fats, and the fact that the situation is one which will take years to remedy, particular interest is attached to the oil-producing crops; their cultivation, conservation, potentialities and use. During the summer the Coconut Conference (Colombo, July 4, 1947) covered much useful ground, papers, chiefly of a directly practical nature, being devoted to the regeneration of plantations, the use of manures, the value of combining animal husbandry with coconut cultivation, problems of soil conservation, the control of insect pests, and problems of co-operation and marketing of coconut products. This report will undoubtedly prove of interest and value to scientific workers and members of the planting community in other tropical regions where the coconut is an important crop.

\section{Marriage Hygiene}

Marriage Hygiene, a quarterly journal published before the War, has been revived. The second series commenced with the issue of August 1947. The managing editor, Dr. A. P. Pillay, is an Indian. $\mathrm{He}_{e}$ is supported by a staff of editors representing Australia, Britain, China, Europe, the Far East, the Middle East, South Africa, South America, and the United States. It is therefore an international production. The British editor is Dr. Norman Haire, and the distribution in Britain is in the hands of $H . K$. Lewis and Co., Ltd., 136 Gower Street, London, W.C.1. The annual subscription is $22 s$. The August issue comprises sixty-four pages of articles, notes and comments, reviews and the like. An examination of this material shows that it is a journal of sexology rather than of marriage. Some of the subjects discussed are frigidity, sterility tests, incest, male sexual disorders, transvestism, and necrology. Such a journal, treating sexual phenomena with scientific detachment and in uninhibited detail, should serve a useful purpose in providing a forum for free discussion and the interchange of clinical data. It is to be hoped, however, that the title will be changed to place the emphasis where it properly belongsupon sex rather than marriage.

\section{Cosmic Rays and Cancer}

Sky and Telescope of July has an article with this title, which describes the experiments of Dr. Frank H. J. Figge, of the University of Maryland Medical School, on mice. Male mice were injected with the cancer-inducing substance, methylcholanthrene, and were then distributed in eight cages, five of which were covered with quarter-inch plates of lead. When cosmic rays pass through thin sheets of lead, showers are produced, thus intensifying the effects of cosmic radiation; and the cages were so arranged that various groups of mice were differently exposed to the scattered cosmic radiation during the five months of experimentation. Those so exposed developed tumours in an average period of 8.5 weeks, while 11 weeks were required for those exposed to normal cosmic rays. Other experiments showed the greater susceptibility of mice exposed to cosmic-ray showers. It is true that direct radiation is less effective than secondary showers; but its effect over a life-time seems to be cumulative. Perhaps architects of the future may be called upon to assist in arresting the development of cancer by choosing building materials which will minimize the effect of cosmic-ray showers.

\section{Library of the History of Medicine, Yale}

THE report for the year 1946-47 of the Historical Library of Yale University School of Medicine records the safe receipt, with only one damaged volume, of the Klebs Library from Geneva, where it was packed and stored in 1943 by the deputy librarian of the United Nations Library. The report also records the circumstances in which Dr. Henry Sigerist resigned in 1947 the chair of the History of Medicine in Johns Hopkins University, a chair which he had held for fifteen years, in order to devote himself to his eight-volume history of medicine. This great act of devotion to scholarship has been facilitated by the appointment of Dr. Sigerist as a professorial research associate of Yale University, with affiliation to the Historical Library of the School of Medicine. This appointment will enable him to continue his historical work at Pura, near Lugano. The first volume of his history of medicine is now nearing completion and will be published by the Oxford University Press.

\section{Fitzwilliam Museum, Cambridge}

THE annual report of the Fitzwilliam Museum, Cambridge, for the year ending December 31, 1946, has been issued. It is the last report with which Mr. Louis Clarke, to whom the Museum is so much indebted, is concerned. His successor, Mr. Carl Winter, formerly deputy-keeper of the Department of Paintings in the Victoria and Albert Museum, London, is now in charge. The report follows the usual lines, and a number of important gifts and acquisitions have been received. Outstanding is Mr. Raphael's great, green jade recumbent buffalo (Han dynasty), which weighs no less than $56 \mathrm{lb}$. But there are also many other valuable additions to the collections in all the various departments. 